\title{
肩関節石灰沈着性腱板炎の病態に関する研究 一特に石灰化結晶の微細構造について一
}

\author{
岡山大学医学部整形外科学教室（主任：田辺剛造教授） \\ 石川 正志
}

（昭和59年 2 月 14 日受稿）

\begin{abstract}
Key words : 局関節石灰沈着性腱板炎,
ハイドロキシアパタイト結晶,

走查電子顕微鏡
\end{abstract}

\section{緒言}

肩関節石灰沈着性腱板炎 (Calcified Tendinitis of the Shoulder : CTS と略す)は，かな り頻度の高い疾患であり，石灰化物が局峰下滑 液包に破れるときに強い炎症反応を誘発すると されている．中年令者の腕を外転位で使用する 軽作業者に多いと言われる。

Bosworth $^{3)}$ は，成人会社員の $2.7 \%$ 石灰沈 着がみられたと報告している。

しかし，その石灰沈着の発生機序あるいは炎 症発現の病態はよく解明されていない。一般的 に, 腱板の膠原線維における異常な老化過程が 石灰化現象を生ずると考之られている，Bate$\mathrm{man}^{2)}$ は，初期には膠原線維の肥大が起り腫脹 と浮腫が起った後に血液供給不足のために娄繀 化し，線維間に間淂が生じ，さらに細胞成分は 減少すると述べている，変性した組織の中では， 酸化の欠如が起り炭酸がス形成が減少するとと もに酸塩基平衡がぐれアルカリ性となってカ ルシウムの沈殿が促進されるとした。しかし， Uhthoff ${ }^{22)}$ は，石灭沈着のある腱の光顕および 電顕藓察により，腱の退行変性は認められず， 石灰沈着は組織の酸素分圧の低下により, 腱が 線維性軟骨に変性し，軟骨細胞により石灰化が おきると述へている。いずれにしてもCTSに おける石灰化の機序はなお不明な点が多い。ま た，石灰化物の形状や炎症発現との関連につい ても詳しい報告はない。

本研究では，CTS 症例における穿刺吸引ある
いは手術時に摘出した石灰化物および切除標本 について光顕, 走查電顕 (SEM と略す) て観察 し，石灰化物の微細構造を検索した。さらに石 灰化結晶成分については赤外線分析で成分同定 を行い，結晶の微細構造と成分との関連を検討 した。さらに解剖屍体から採取した肩腱板を光 顕および SEM 観察し, 腱板の変性と石灰化の 関連について検討した。また，これらの結果か らCTSの発生機度について考察した。

\section{研究材料および方法}

\section{1. 研究材料}

研究材料には，CTSの臨床例上り穿刺吸引 （図 1-A）あるいは手術的に摘出した石灰化物 （図 1-B）および組織標本と解剖屍体標本より採 取した回旋筋腱板（図 1-C）を用いた。

穿刺吸引により石灰化物を吸引できたものは 4 例（45才〜47才，いずれも女性）であった。

手術的に摘出したものは 3 例（51才，女性； 51才，女性，71才，男性）であった（図 2 ）。肩峰 下滑液包内の石灰化物と石灰沈着のある腱の一 部を摘出した。臨床例は全て片側例であった。

症例はレントゲン唡査で 3 型に分類（小比賀 7 ) の分類）できるが, 症例 1 は diffuse type で辺

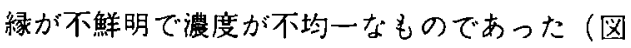
2-A). 症例 2 は diffuse type と sharp type $の$ 中間型であった（図 2-B）。症例 3 は sharp type で辺縁が鮮明で濃度がほほ均一なものであった (図 2-C).

屍体標本（系統解剖）より採取した腱板は， 

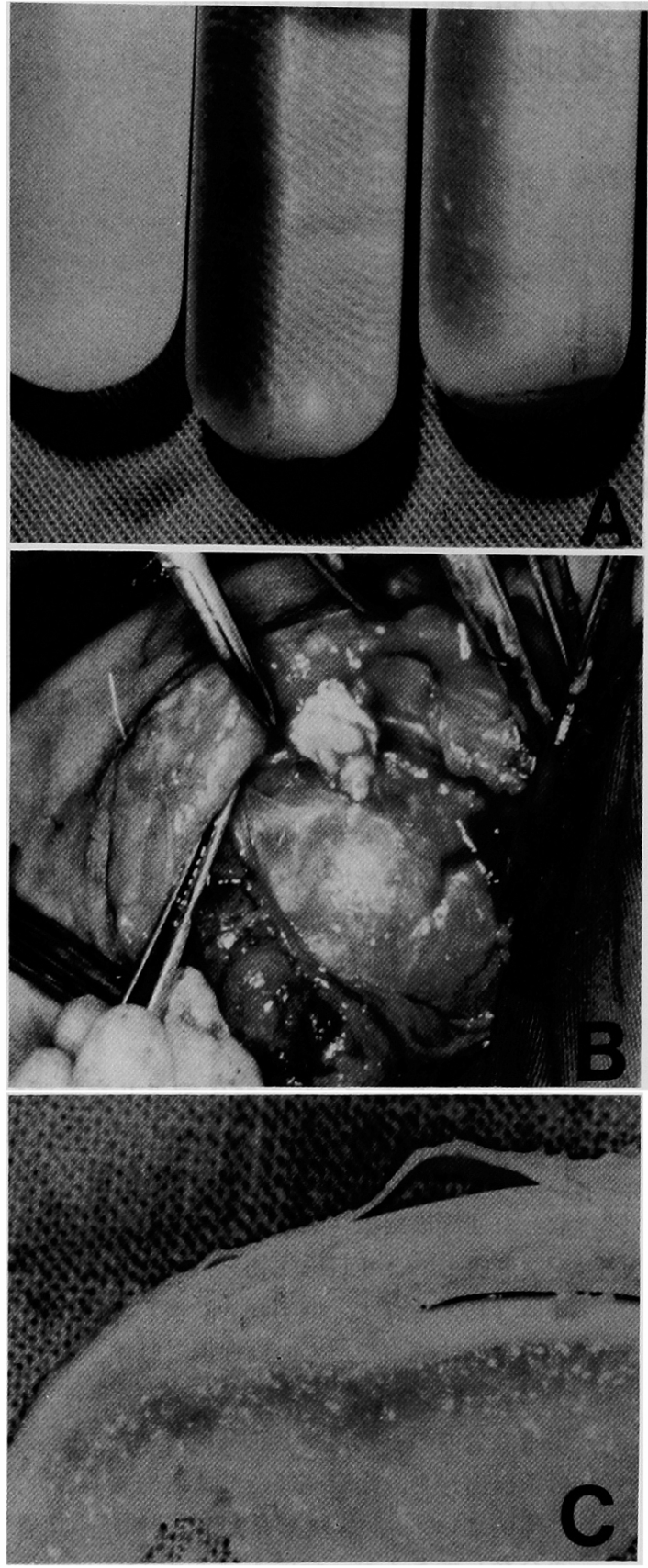

図 1 採取標本 ( A : 穿刺液, B：手術摘出標本, $C:$ 屍体切り出し標本)

9 体18関節で男性 6 体と女性 3 体であった。死 亡時年令は63才から89才で平均78.5才であり， 死因は特に慢性関節リウマチなどの関節障害の あるものはない，上腕骨骨頭の一部，大結節，
棘上筋腱, 棘下筋腱部を一塊として採取し た。

\section{2 . 研究方法}

手術によって摘出された石灰化物質を含 む腱板は，10\%中性ホルマリンで固定し， H.E，マッソン・トリクローム，コッサ染色 を行ない光顕観察した。また，結晶成分に ついては，偏光顕微鏡で検鏡した。腱板の 一部は SEM 用の試料として用い, $2.5 \%$ グ ルタール・アルデヒドにて固定，カコジル酸 緩衝液で洗浄後オスミウム酸後固定を行な った，脱水扩よび臨界点乾燥を行い，金· パラジウム蒸着後, SEM（日本電子製, M3 型）観察を行なった。

手術ならびに穿刺吸引して得られた石灰 化結晶物（図 3 ）は光顕および SEM で観 察し，一部は赤外線吸収スペクトル分析に よって成分の同定を行なった（表 1 ）。

屍体から採取した標本は，棘上筋腱およ び上腕骨大結節を腱線維の走行にそって垂 直に切り出し, 光顕標本を作製した， $\mathrm{HE}$ 染色およびマッソン・トリクローム染色を 行ない，通常の光顕観察をするとともに偏 光顕微鏡により検鏡した。また，棘上筋腱 の大結節付着部より $1 \sim 2 \mathrm{~cm}$ 中枢の critical zone と呼ばれている部位の腱を SEM で観察した。

\section{結}

\section{果}

\section{1. 光顕観察}

i ）穿刺吸引による石灰化物

穿刺吸引によって採取された石灰化物の 塗沫標本は, 偏光顕微鏡下では顆粒状の結 晶を示す、ほぼ同一の形状を呈するが，種 々の大きさの結晶で細胞成分などは認めら れない(図 3 )。これらの結晶成分は偏光像 を呈するが，結晶成分を同定できる固有の 偏光は認められない。

ii ) 手術標本

石灰沈着は, 腱様部のコラーゲン線維の走行 にそっており，離開した線維間に顆粒状の集塊 として見られ，エオジンに濃染した基質の中に顆 粒様結晶を認める（図 4-A）。偏光顕微鏡では, 

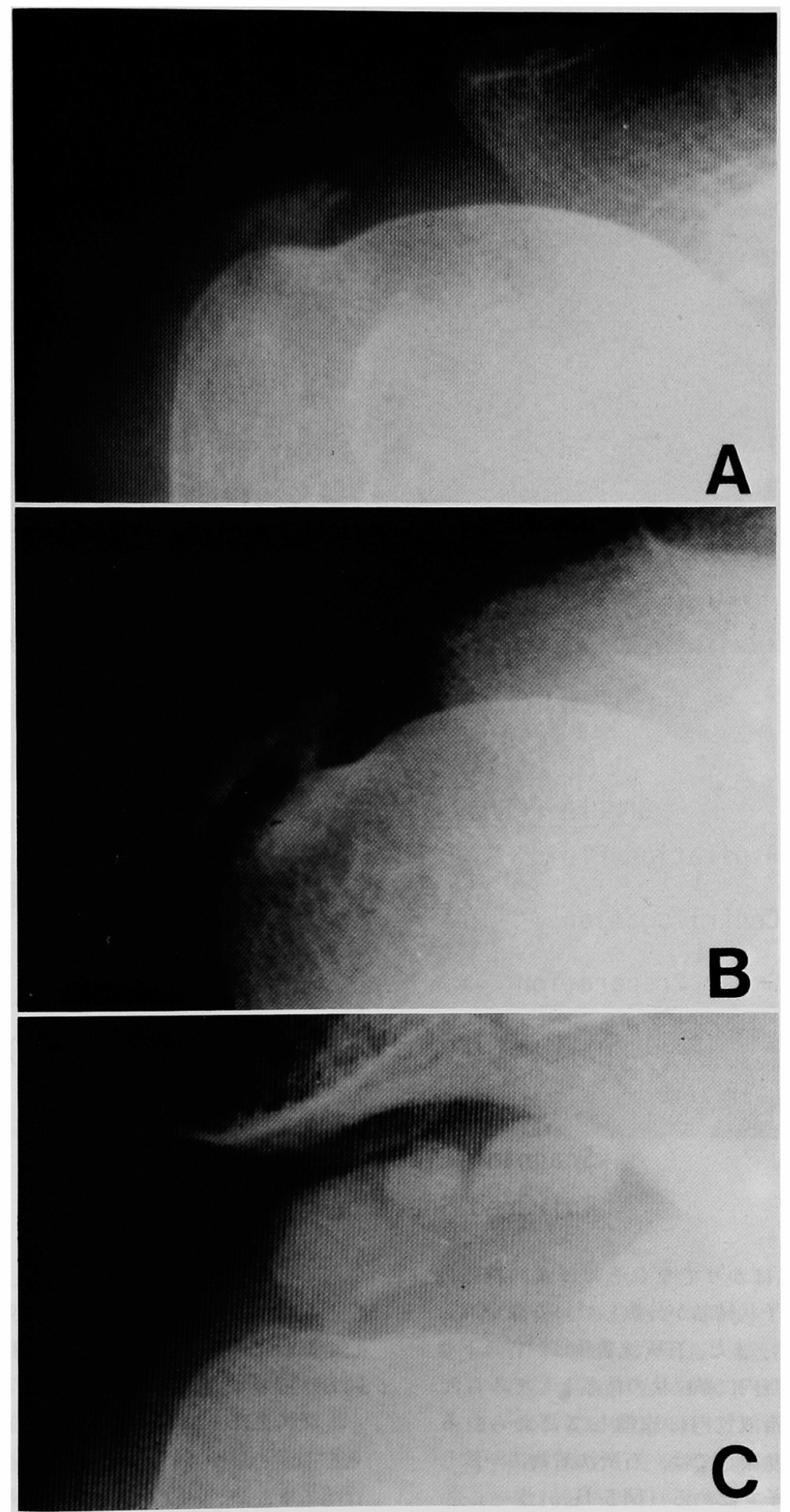

図2手術症例の X線所見 


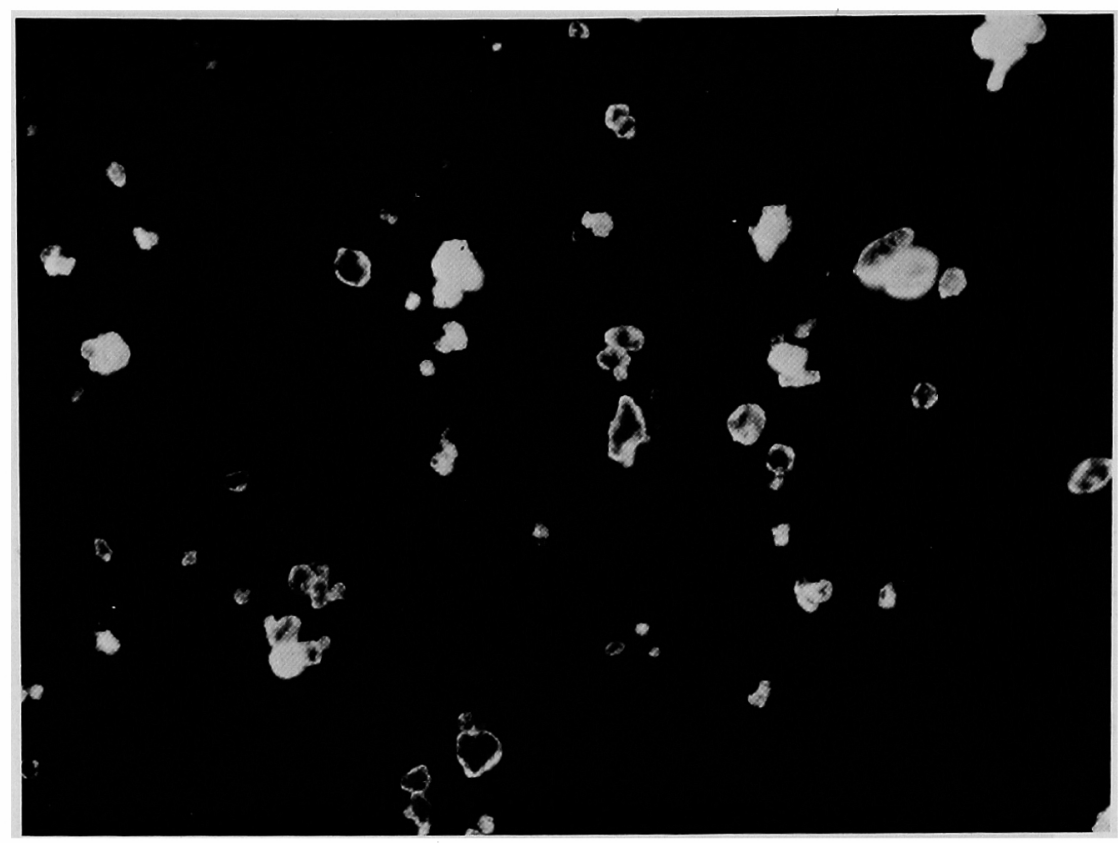

図 3 穿刺吸引で採取した石灰化物の偏光顕微鏡像 $(\times 400)$

表 1 試料作製法

\section{SAMPLE PREPARATION}

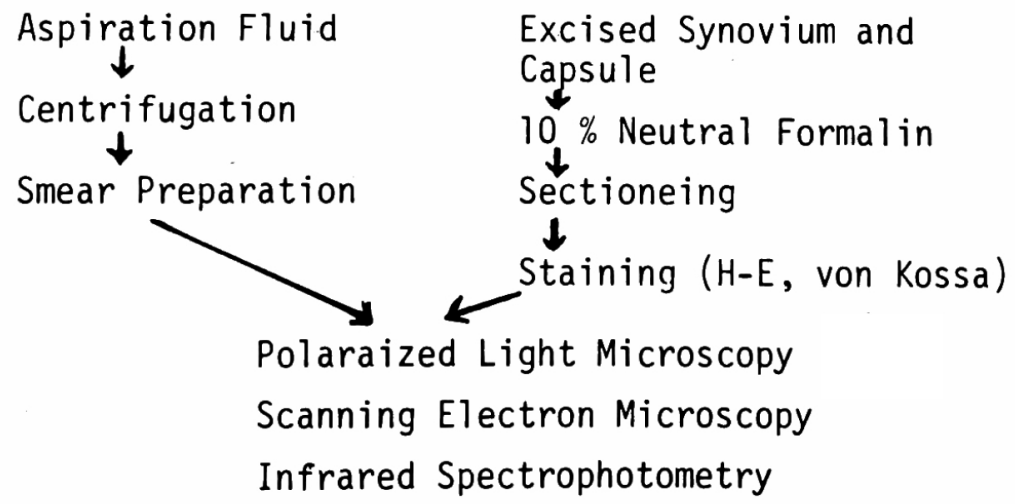

集塊状の結晶ばかりでなくその周囲の線維内 にも細かい粒子状結晶が分散している像がみら れる(図 4-B ). また, 石灰沈着物は, 肩峰下滑 液包周囲で小胞内に顆粒状の結晶としてみられ るが，一部は滑液包内に放散して認められる (図 5 ).コッサ染色では, 石死沈着物に一致し て黒染する粒子を認める（図 5-B）.

iii）屍体標本

回旋筋腱板特に棘上筋腱は, 筋腱移行部から
骨附着部までが 2 - $3 \mathrm{~cm}$ と長く, 上面は肩峰下 滑液包に下面は肩関節腔に面し（図 1-C），一見 して血行に乏しいことがわかる.また, 骨附着部 における境界は，ほとんどの例で不鮮明である。 光顕的には, 腱板の骨附着部において変性所 見を示すことが多い。腱線維と軟骨組織との移 行部では、コラーゲン線維の断裂や皸裂が全例 にみられた(図6)。皸裂形成部では，硝子様変 性とともに軟骨細胞の cluster 形成や基質染色 


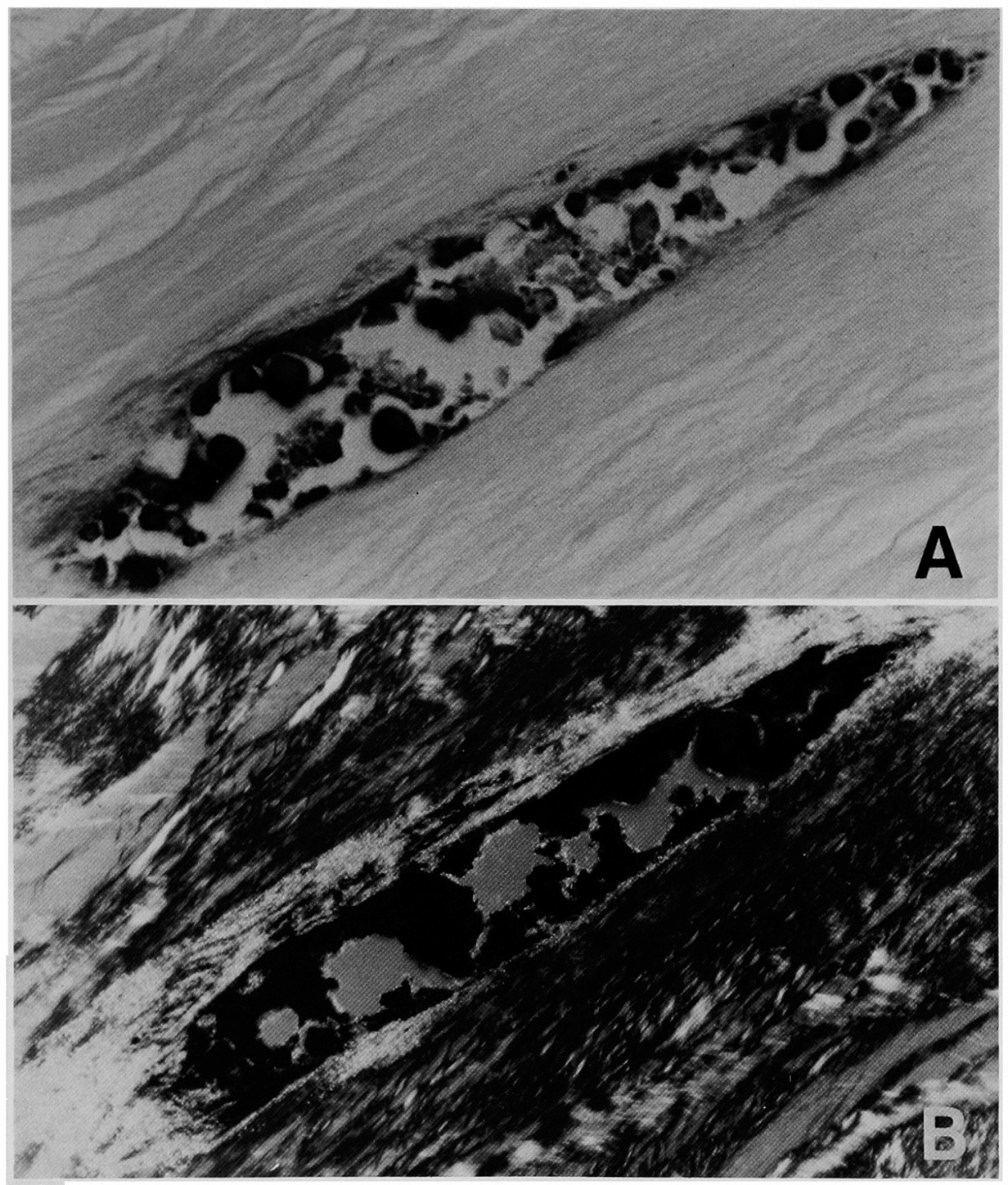

図 4 手術摘出標本の光顕像 (A:H-E 染色 $\times 400$, $\mathrm{B}$ : 偏光顕微鏡像 $\times 400)$

性の増加がみられた(図 6-A)。コラーゲン線維 の骨質埋入部におけるへマトキシリンに青染す る tidemark は, 変性の少ないものでは乱れな いが，腱の変性とともに染色性が不規則となり， その厚さも増し，不整となる。骨附着部におけ る基質には微細な石灰化をみる（図 7-A）。 腱中央部では，骨附着部でみたコラーゲン線維 束の皸裂にそって硝子様変性や壊死に伴う線維
細胞の増殖がみられる(図6,7).

筋腱移行部では，周囲に血管が富むようにな り，変性所見は少ない（図 7-B)。

2 . 走査電顕検鏡所見

手術的に摘出した石灰沈着物は, SEM では 数 $\mu$ 一数 $10 \mu$ の大小さまざまな顆粒状の結晶の 集族としてみられる。その集族中には，線維組 織などは認められず，一定の結晶成分のみをみ 

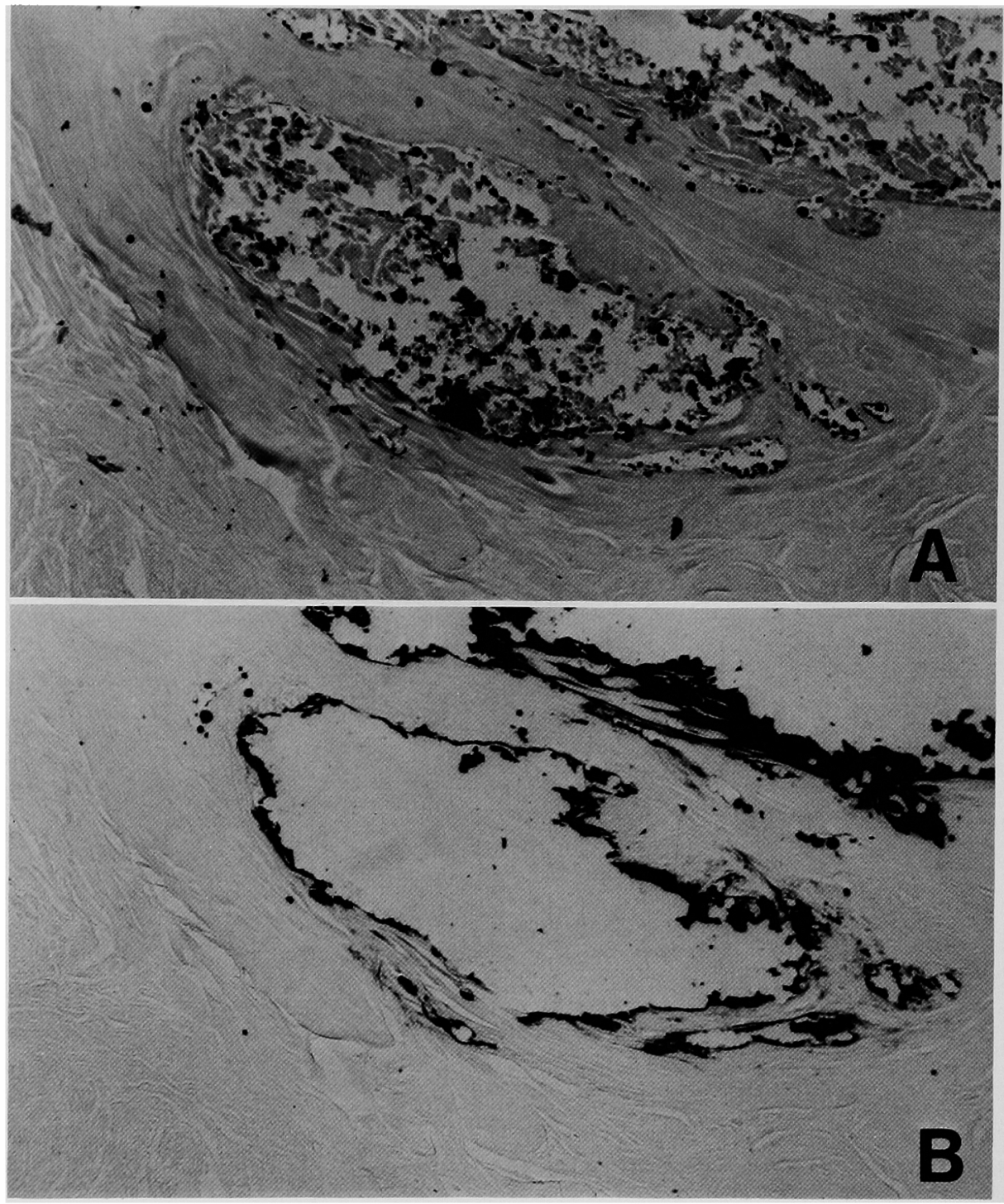

図 5 肩峰下滑液包に放散した石灰化物

(A：H-E 染色 $\times 250 ， B ： コ ッ$ 染色 $\times 250)$

る(図 8 )。ささらに高倍率では,この顆粒状結晶 はより微細な結晶からなっており，その大きさ

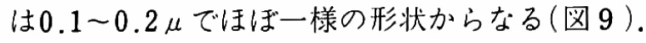
石灰沈着部周囲の腱線維部分では，比較的小 型の結晶（数 $\mu$ ) が, コラーゲン線維の間に散 在して沈着し, 一部ではコラーゲン線維の走行 にそって生じた皸裂に集族する（図10）。

一方，穿刺吸引した石扊化物を遠沈した標本
でも同様の顆粒様結晶を認めた（図11）。

3 . 石灰沈着物の分析

摘出および穿刺吸引した石灰化物を同定する にあたり，市販のハイドロキシアパタイト(Clarkson chemical Comp.) をコントロールとして分 析し，その上で検定試料について同様の分析波 をとり比較した。吸収波の解析からほぼ1050の 部に吸収波を認め, 石灰化物はハイドロキシア 
局関節石灰沈着性腱板炎の病態に関する研究一特に石灰化結晶の微細構造について
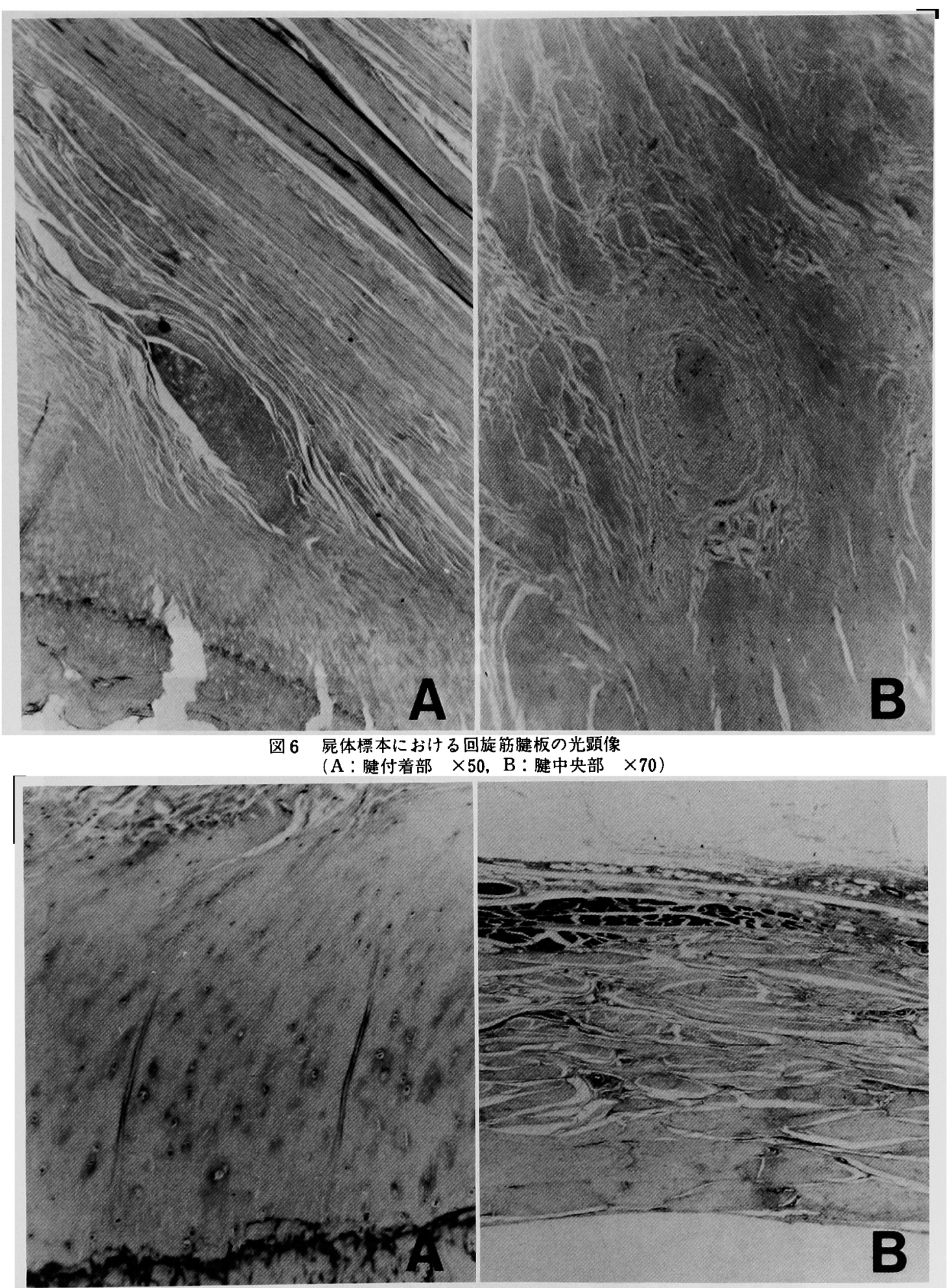

図 7 屍体標本における光顕像

$(\mathrm{A}$ ：骨頭埋入部 $\times 70, B ：$ 筋腱移行部 $\times 20)$ 


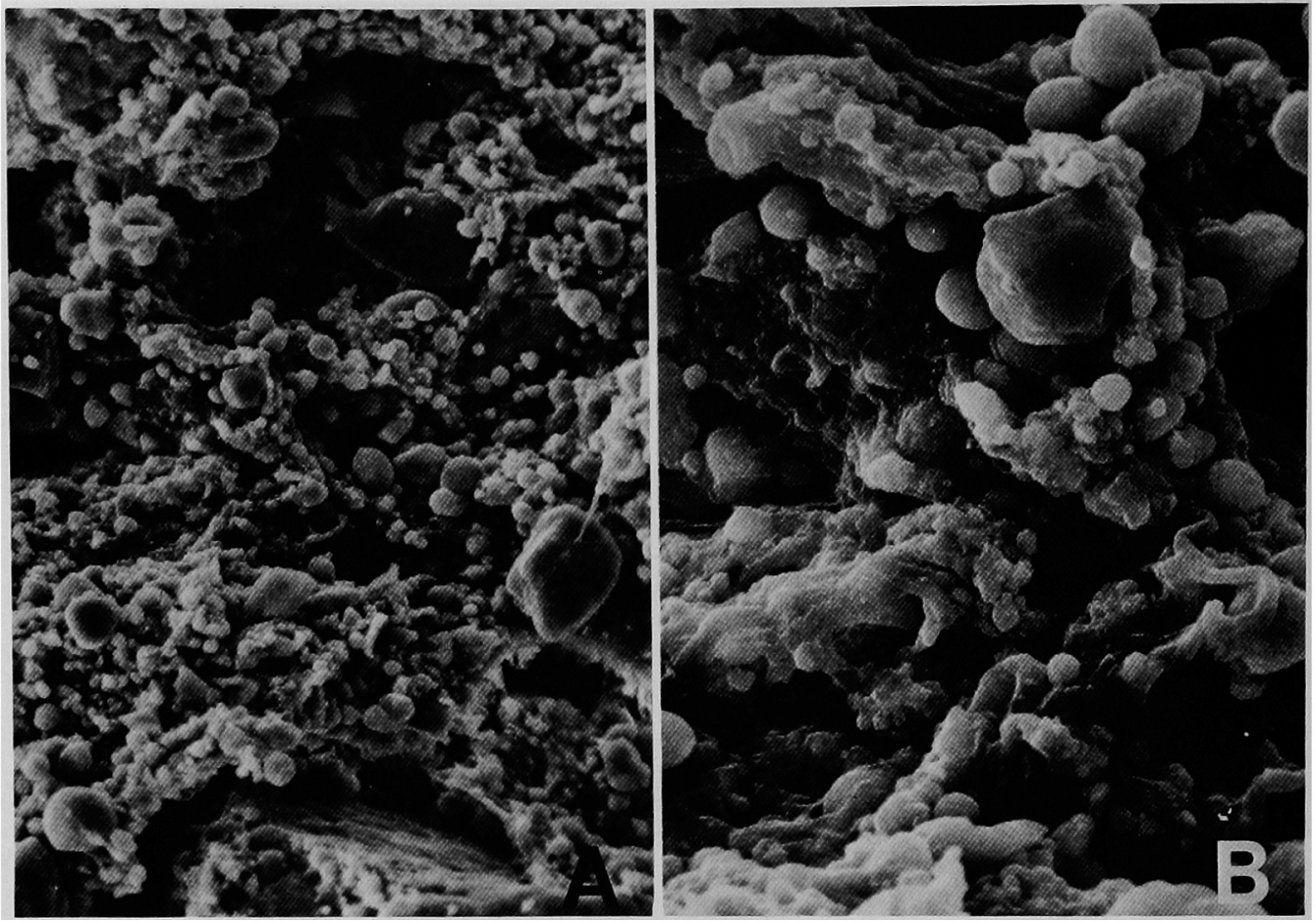

図 8 摘出石灰化物の SEM 像

$(\mathrm{A}: \times 300 \quad \mathrm{~B}: \times 1,000)$

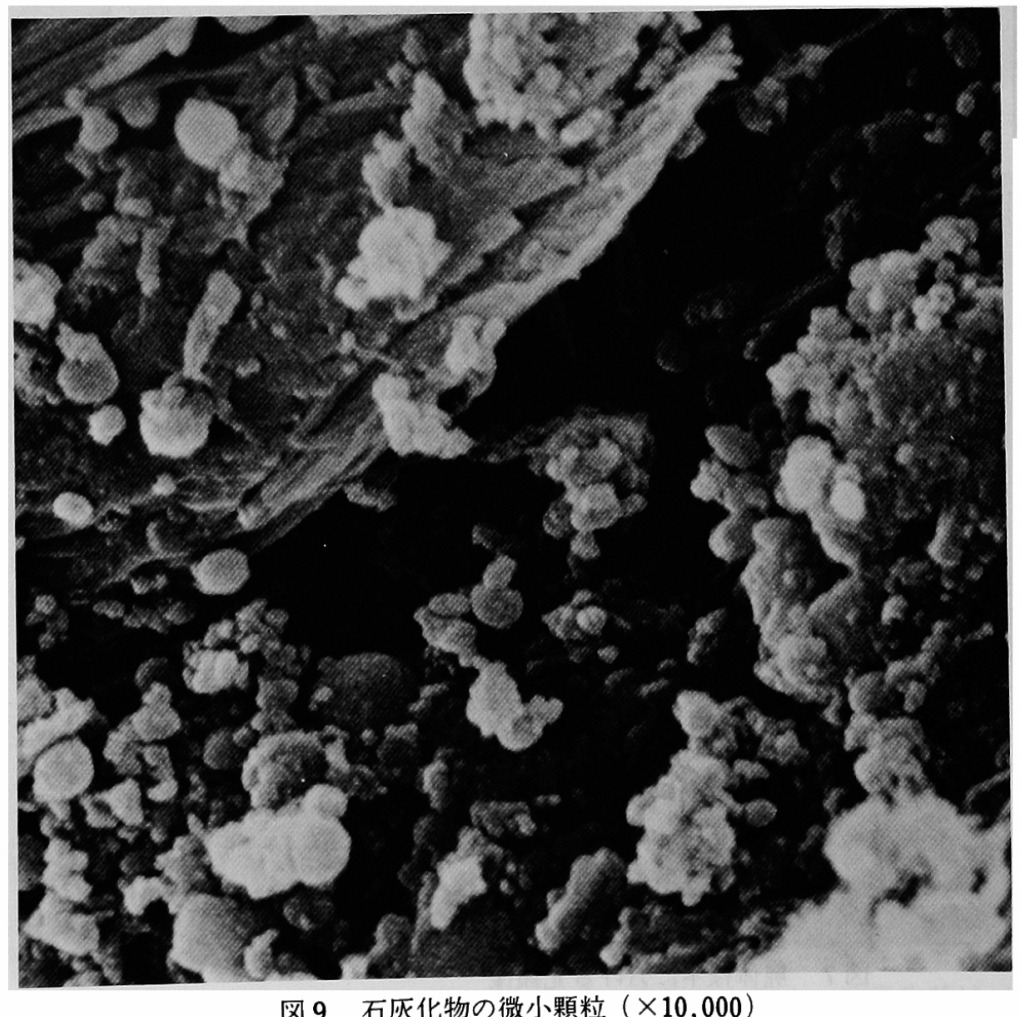

図 9 石灰化物の微小顆粒 $(\times 10,000)$ 


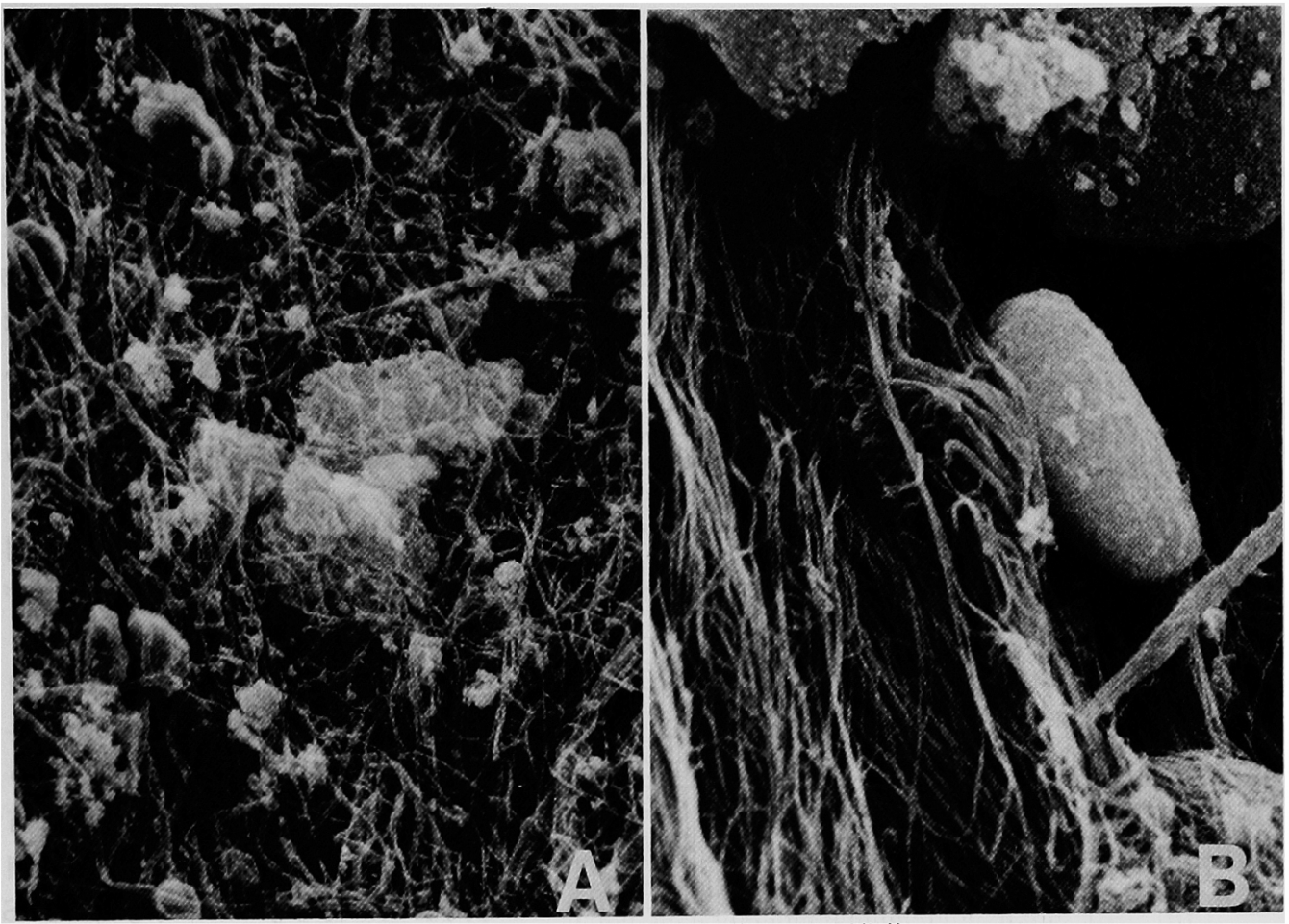

図10 コラーゲン線維間に沈着した石灰化物

$(\mathrm{A}: \times 1,000 \quad \mathrm{~B}: \times 3,000)$

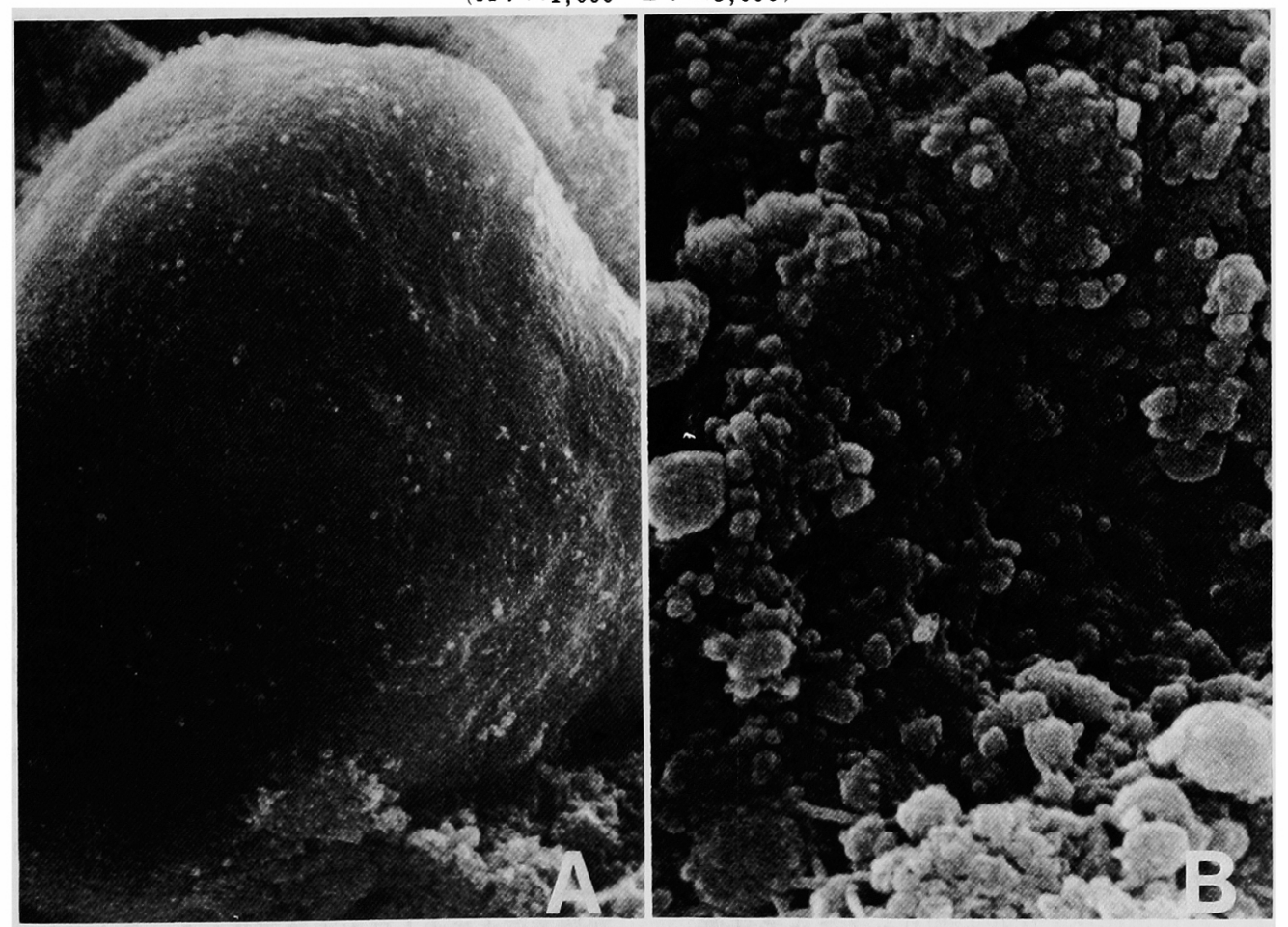

図11穿刺吸引採取した石灰化物のSEM 像

$$
(\mathrm{A}: \times 3,000 \quad \mathrm{~B}: \times 10,000)
$$




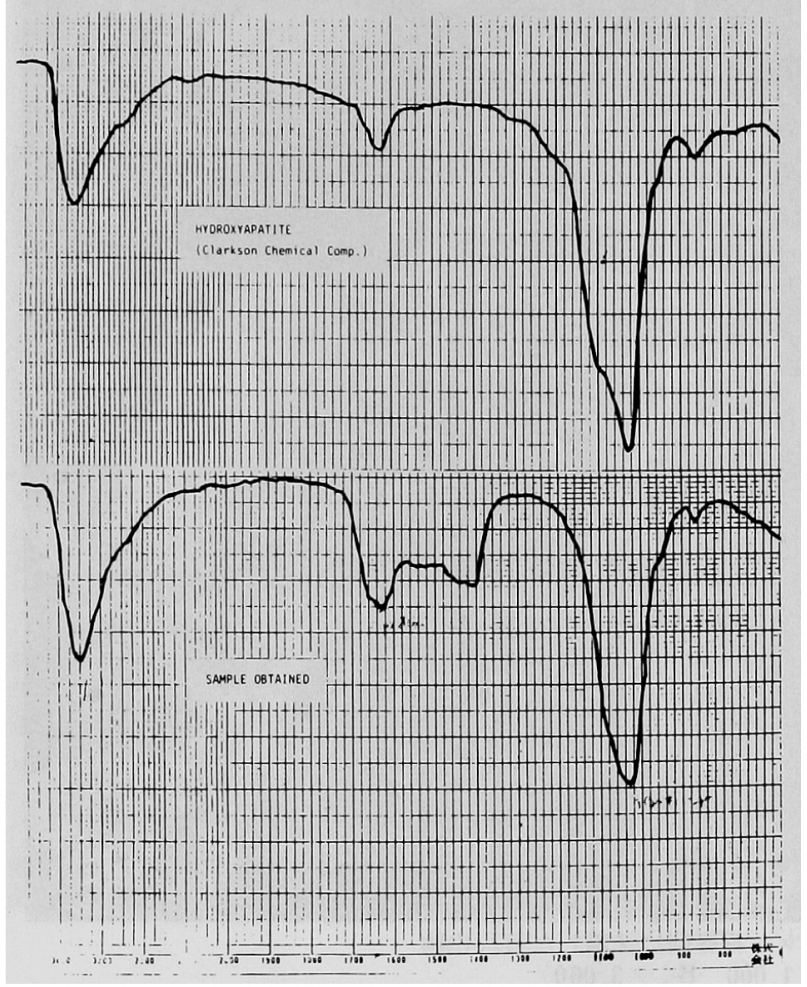

图12 摘出石灰化物の赤外線分析 （上：市販ハイドロキシアパタイト， 下：摘出石灰化物)

パタイトと同定された（図12）。

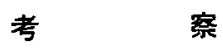

20世紀初期にX線による診断技術が導入され、 1907年, Painter ${ }^{18)}$ は上腕骨大結節上部の石存 化陰影を認めた。彼は，これが三角筋下滑液包 の肥厚によるものであると考えたが，手術によ って三角筋下滑液包内に千ーズ様の石兏化物を 発見した，1908年，Codman"4)は手術により三 角筋下滑液包には癒着以外には認めるべき変化 はなく，沈着物は滑液包の下で大結節の上にあ ることを確かめた，彼は棘上筋腱の石死化の結 果，棘上筋腱の断裂が起りうると考之，その後 Akerson $^{5)}$ とともに腱板の研究を行い, 断裂が 石乍化の結果起った欠損である可能性あるいは 断裂の修復機能で石灰化が起りうることを示唆 した.1932年，Elmeslie ${ }^{8)}$ は 7 例を手術しその
病理学的研究と沈着物質の同定を行な い，沈着物のほとんどがリン酸カルシ ウムであり少量の炭酸カルシウムが含 まれていることを証明した。また，棘 上筋腱の断裂が最初におこり，そこに 石扊沈着を生じ，これが刺激性の異物 として働くために症状が起ると考えた。

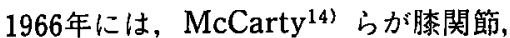
手関節，肘関節および肩関節における 石灰沈着性の炎症組織では，ハイド口 キシアパタイト結晶が含まれているこ とを報告した。こうした研究から，有 関節石灰沈着性腱板炎としての疾患が 確立されてきている。

回旋筋腱板の石灰化は頻度が高く， 日常診療でもしばしばみられる。Bosworth $^{3)}$ は，約 6000 人の成人会社員の 検診を行ない, $2.7 \% に$ 肩関節周囲の石 兏化を認めた。信原 ${ }^{16)}$ は，肩関節周囲 炎と診断されたもののうち $3 \%$ CTS があったと報告している，その他CTS について多くの報告があるが，好発年 令は40〜50才代で，右側に多く，主婦， 事務職等軽作業者に多いとする点では 一致している。しかし、性差について は報告により異なる。1,3,7,10,11,13,21,22,23) 石灰沈着部位は，回旋筋腱の中では棘上筋腱が

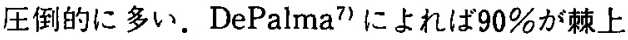
筋腱内である。

棘上筋は肩甲骨棘上窩からおこり上腕骨大結 節に附着し，肩の外転筋，上腕骨骨頭の stabilizer として働く，䊂上筋腱は，上面は肩峰下滑 液包の床面と癦合し, 滑液包の上には coracoacromial archがあり，これらによって第 2 肩 関節と呼ばれるものを構成している，下面は肩 関節包と接し、これとも癒合して骨頭表面をお おう，棘上筋腱は上腕骨頌部に対してほとんど $0^{\circ}$ の角度で大結節に附着するが，上腕を完全挙 上すれしば約 $140^{\circ} の$ 角度を成す9)、棘上筋は主に肩甲 上動脈，前および後上腕回旋動脈によって養なわ れている。しかし，腱部分が長く筋腱移行部より 骨附着部まで成人日本人で平均 $2.5 \mathrm{~cm}^{9)}$ あり，コ ラーゲン線維が密に並んでいるために血行にき 
LW.

Rathbum ${ }^{19)}$, Rothman ${ }^{20)} ら は$ 腱板の血行につ いて研究し、棘上筋腱附着部の中枢側に hypovolemic area があること,また上腕骨内転位で は骨頭による圧迫で血液容量が減少することを 確かめた。そして，他の回旋筋腱には hypovolemic area がほとんど認められないことも報 告している.

棘上筋腱は，㥊状組織と呼ばれる線維軟骨で 大結節に附着し，骨に接して薄い石灰化層があ り，HE 染色で青染するため Codman' ${ }^{6)}$ はこれ を blue line と呼んだ。図7-Aでみるようにへ マトキシリンに濃染する部分がこれに相当する と考えられるが、これに続いて線維軟骨の棚状 配列がみられる。この㥊状組織の中枢約 $2.5 \mathrm{~cm}$ で腱板の断裂，石灰化が起りやすいので彼はこ の部を critical zone と名付けた. critical zone は、 Rothman ${ }^{20)} ら の$ 示した hypovolemic area に一致する。また，上腕の内外転で㥊状組織で は屈曲はほとんど起らず，その中枢の腱線維部 で屈曲が起り，この部に力が集中すると考えら れる。このように, critical zoneでは, ストレ ス，摩擦を受けやすく，血行に乏しいために変 性が起りやすいといえる。本研究における薿体 標本の観察でも，腱附着部の変性が最も強く， 筋腱移行部ではほとんど変性は認められなかっ た。また，臨床例でも腱内石灰化はすべて棘上 筋腱内にあった。

CTSのX線像は， diffuse なものから sharp なものまであり，沈着物の性状はコロイド状な いしペースト状のものから硬くチョーク状のも のまで多様である。しかし，SEM 観察によれ ば、各々の石灰化物は形態的に類似した微細結 晶より構成されている(図 $8,9,10,11$ )。また， 赤外線分析においても同じ吸收波パターンを示 し、すべてハイドロキシアハタイトと同定され た。うしたことから，石灰化物質の化学的組 成には差がなく，性状の違いは Moseley ${ }^{15)} の$ 言うように成分の違いではなく溶解度の違いに よる大きさの違いであると考えられた．

CTSの成因については多くの説が発表されて いるが,なおその発生機序は明らかでない. 1945 年, Howorth ${ }^{11}$ はCTSの顕微鏡的観察を行な
い，腱線維が乘らかく粗造化して変性し変性の 強い部分に石灰化が多いことからまずはじめに 腱の変性が起り，ついでカルシウム塩の沈着が 起ると考えた。腱の変性は, 持続するそ血状態 と繰り返される摩擦のためであり，結合織の增殖 と血管の増加は修復のために起ると考えた. Key ${ }^{12)}$ は，カルシウム塩は蛋白により保持されており， 微小外傷によって変性や壊死が起っている部分 では炭酸塩が隇少しアルカリ性に傾きそここで カルシウム塩が沈着すると考之た。1972年, Ba$\operatorname{teman}^{2)}$ は回旋筋腱の附着部はコラーゲン線維 が密に集束して血行が悪いこと, 多方向より機 械的な負荷がかかるために異常なコラーゲン線 維の老化が起り，まず線維が肥厚し，ついで血 液供給の不足から線維の萎繀が起り線維間に間 隚ができるとともに核は減少する。その過程で 酸化の異常により炭酸がスの産生が減少し、ア ルカリ性に傾きカルシウムの沈着が起ると述べ た. 1976年, Uhthoff ${ }^{22)}$ は持続する組織の酸素 分压の低下が原因であると考之，低酸素状態に より腱が線維軟骨に変性し，軟骨細胞により石 灰化が起き，一方石灰化した部位に血管が侵入 すれば、會食細胞によって石灰化物が會食され 吸収されるとした。石灰化とその吸収は同時に 行なわれているとしている。

棘上筋腱は, 解剖学的に機械的ストレスを受 けやすく血行に乏しいために変性が起りやすい と考之られる。本研究においても, 腱の骨附着 部付近では変性が著明で線維の断裂や硝子様変 性が認められた。組織中のカルシウム塩は, 蛋 白複合体としてあるいはりン酸塩, 炭酸塩とし て溶解または㲘濁された状態にあり，変性した 組織がアルカリ化あるいは炭酸がスの減少によ ってカルシウム塩の結晶が発生するものと考之 られる.一方, 硝子样変性が起っている部位に はカルシウム塩の沈着が起りやすいとする病的 石灰化に対する Wells ${ }^{241}$ の理論によれば，変性 した腱の状態は種々の理由で非常に石灰化が起 りやすい状態にあるといえる。また，石灰化は 变性が多発する腱の骨附着部に起っていると考 えられる.CTSの発生に関して, 加令ならびに 力学的負荷に上る腱の退行性变性が大きな要因 であり，コラーゲンの断裂，硝子様変性が起り， 
ここに石灰化が誘発されるものと考えられる。

関節内あるいは関節周囲組織の石灰沈着を起 こす疾患としてピロ燐酸カルシウム (CPPD) による偽痛風があるが、CPPDは $4 \sim 10 \mu$ の長 さをもつ四角柱状または立方体状の結晶を呈し， 偏光顕微鏡では陽性の複屈折性を示す結晶と して認識することができる。これに对し，八イ ドロキシアパタイトは，微細な顆粒状結晶から なっており，その直径は0.1 0.2 $\mu$ と小さく偏 光顕微鏡では固有の偏光を示す結晶として同定 することはできない。

本研究の結晶成分の観察からすると, CTS 石灰沈着物は単一のハイドロキシアパタイトで あり、これが局所の溶解度によって㮔々の大き さの顆粒状となって沈着したものと思われる。 この顆粒状石灰化物か，局所においては周峰下 滑液包あるいは肩関節腔内に放出され，結晶誘 発性滑膜炎としての強い炎症を発症せしめるも のといえる.
結語

1) 肩回旋筋腱板の組織学的観察を行ない, 腱 の骨附着部に著明な変性所見を認めた。

2 ) CTSの結晶成分の微細構造と成分の検索を

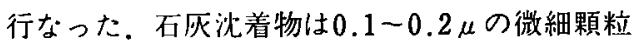
状結晶より構成され，さらに数 $\mu$ 数 $10 \mu \sigma 大$ 小さまざまの顆粒となって集積する。また，結 晶成分の分析でハイドロキシアパタイトと同定 された。

3 ) 腱の加令, 力学的負荷による退行変性と血 行の不足によって石灰の沈着が誘発され，CTS ではハイドロキシアパタイトの結晶が結晶誘発 性滑膜炎を発症せしめるものと考之られた。

椋を終えるに臨み、御校閲を頂いた田辺㓮造教授 に深甚なる謝意を表するとともに，直接御指導を原 いた井上一講師に深謝いたします。また，屍体標本 の採取にあたっては，村上宅郎教授（第 2 解剖学教 室）に御協力頂いたことを記し深謝します。

献

1. Bartels, W.P.: The surgical reatment of acute subacromial bursitis. J. Bone Joint Surg. 22, 120$121,1940$.

2 . Bateman, J.E: The Shoulder and Neck. W.B. Saunders Co., Philadelphia London-Tronto, pp.211218, 1972.

3. Bosworth, B.M: Calcium deposits in the shoulder and subacromial bursitis. JAMA J. Am. Med. Assoc.) 116, 2477-2482, 1941.

4. Codman, E.A: Bursitis subacromialis, or periarthritis of the shoulder joint. Boston Med. Surg. J. 159, 615-644, 1908.

5. Codman, E.A, Akerson, I.B: The pathology associated with rupture of the suparspinatus tendon. Ann. Surg. 93, 348-359, 1931.

6. Codman, E.A: The Shoulder. Thomas Todd. Boston, 1934.

7. DePalma, A.F., Kruper, J.S: Long-term study of shoulder joints afflicted with and treated for calcific tendinitis. Clin. Orthop. 20, 61-72, 1961.

8. Elmslie, R.C.: Calcareous deposits in the supraspinatus. Br. J. Surg. 20, 190-196, 1932.

9. 原 文吉：局甲関節周囲組織の年令的变化について, 日整会誌, 16，833-876，1941.

10. Heggö, O.: Tendinitis calcarea supraspinati. Acta Orthop. Scand. 35, 126-131, 1964.

11. Howorth, M.B.: Calcification of the tendon cuff of the shoulder. Surg. Gynecol. Obstet. 80, 337$345,1945$.

12. Key, J.A.: Calcium deposits in the vicinity of the shoulder and other joints. Ann. Surg. 129, 737755, 1949. 
13. Lippman, R.K.: Observation concerning the calcific cuff deposit. Clin. Orthop. 20, 49-60, 1961.

14. McCarty, D.J., Gatter, R.A.: Reccurent acute inflammation associated with focal apatite crystal deposition. Arthritis Rheum. 9, 804-819, 1966.

15. Moseley, H.F.: Calcified deposits in the rotator cuff. In Shoulder Iesions, 3rd ed. Edinburgh E \& S. Livingstone, pp.99-118, 1969.

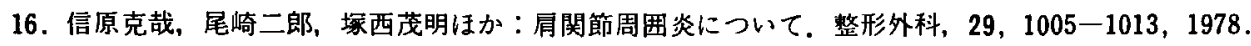

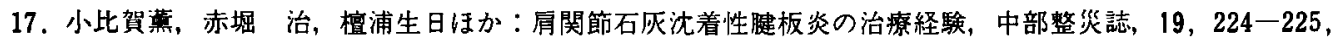
1976.

18. Painter, C.F: Subdeltoid bursitis. Boston Med. Surg. J. 156, 345-349, 1907.

19. Rathbum, J.B., Macnab, I.: The microvascular pattern of the rotator cuff. J. Bone Joint Surg. 52, 540-553, 1970.

20. Rothman, R.H., Parke, W.W.: The vascular anatomy of the rotator cuff. Clin. Orthop. 41, 176$186,1965$.

21. Sandstrom, C.: Peritendinitis calcarea. Am. J. Roent. 40, 1-21, 1938.

22. Uhthoff, H.K., Sarkar, K., Maynard, J.A.: Calcifying tendinitis. Clin. Orthop. 118, 164-168, 1976.

23. Uhthoff, H.K., Sarkar, K.: Calcifying tendinitis. Internat. Orthop. (SICOT) 187-193, 1978.

24. Well, H.G.: Occurrence of pathological calcification. Chemi. Pathol. 5, 489-492, 1924. 
Ultrastructure of calcified substances in calcified tendinitis of the shoulder

\section{Masashi IshIKAWA}

The Department of Orthopaedic Surgery, Okayama University Medical School.

(Director: Prof. G. Tanabe)

Calcified substances from lesions of calcified tendinitis of the shoulder (CTS) were studied by scanning electron microscopy (SEM) and polarized light microscopy. The substances were also analysed by infra-red spectrography. The rotator cuffs of the shoulder in 9 cadavers were observed by light microscopy.

In the histological study of the rotator cuffs, various degenerative changes, such as separation and irregular arrangement of the collagen bundles and hyalinization at the attachment of the rotator cuff tendon to the bone were found. Calcification at the tendon insertion was also detected at the blue line area, which was stained with hematoxylin, while the musculo-tendinous juntion was intact.

Scanning electron micrographs showed that calcified deposits in the CTS lesions were made up of granular crystals $(0.1-0.2 \mu$ in diameter) accumulating into round particles (3-10 $\mu$ in diameter). Infra-red spectrography demonstrated that the deposits were similar to commercially available hydroxyapatite.

Calcification can be induced by aging and mechanical stresses which proceed degenerative changes and circulatory disturbances at the tendon insertion. The calcified crystals, composed of hydroxyapatite, can push into the subacromial bursa and cause crystal-induced synovitis. 